\title{
Algoritma K-Means Clustering untuk Menentukan Nilai Gizi Balita
}

\author{
Eni Irfiani ${ }^{\# 1}$, Siti Sulistia Rani ${ }^{* 2}$

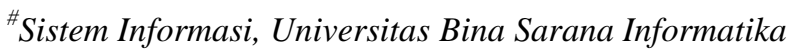 \\ Jl. Kamal Raya No. 18 Ring Road Barat Cengkareng Jakarta Barat \\ ${ }^{1}$ eni.enfebsi.ac.id \\ *STMIK Nusa Mandiri \\ Jl. Kramat Raya No. 18 Jakarta Pusat \\ ${ }^{2}$ ranimuzaeni2gmail.com
}

\begin{abstract}
Abstrak-Gizi sangat dibutuhkan bagi tubuh manusia, terutama pada usia balita dan anak-anak, nilai gizi yang seimbang sangat baik dalam proses tumbuh kembang anak, meningkatkan kemampuan belajar yang baik, serta memberikan dampak positif untuk perkembangannya di masa depan. Permasalahan saat ini pada Desa Sukamantri masih kurangnya pengetahuan dasar orang tua dan para kader Posyandu mengenai nilai gizi seimbang bagi balita, ditemukan balita yang kurang gizi serta obesitas belum adanya pengelompokkan data berdasarkan karakteristik nilai gisi balita. Pengklasteran (clustering) merupakan metode yang cukup popular dan paling sering digunakan dalam pengolahan data pencitraan medis, biometrik dan bidang yang terkait karena kesederhanaannya serta efektif dalam mengelompokan data dengan ukuran besar berdasarkan kecepatan pemrosesan dengan menempatkan objek-objek ke dalam kelas-kelas yang memiliki kemiripan. Dalam penelitian ini akan di kelompokan atau klasterisasi nilai gizi balita dengan acuan parameter tinggi badan balita dan berat badan balita menggunakan algoritma K-Means Clustering menjadi beberapa kategori yaitu obesitas, gizi lebih, gizi baik, gizi kurang dan gizi buruk. Dengan klasterisasi menggunakan algoritma K-Means dapat mengklasifikasi nilai gizi balita secara umum agar dapat digunakan sebagai landasan pencegahan dini bagi para kader posyandu menanggulangi gizi buruk serta obesitas. Berdasarkan hasil penelitian ditemukan masih terdapat $30 \%$ balita obesitas dan $11 \%$ kekurangan gizi, untuk itu perlu adanya penanganan dan perhatian dari kader Posyandu dan Puskesmas terkait kepada orang tua balita tersebut.
\end{abstract}

Kata kunci - Clustering, K-Means, Nilai Gizi, Balita, Posyandu

\section{PENDAHULUAN}

Tumbuh kembang anak tentulah menjadi salah satu perhatian yang sangat utama bagi para orang tua, terutama dalam hal gizi seimbang. Saat ini di Indonesia sendiri masih menghadapi masalah gizi ganda, yaitu kekurangan dan kelebihan gizi. Menurut Riset Kesehatan Dasar Kementrian Kesehatan pada tahun 2013 mengungkapkan 1 dari 3 anak tergolong pendek (stunting) akibat kekurangan gizi menahun sehingga berisiko mengalami gangguan pertumbuhan dan perkembangan. Di sisi lain, prevalensi kelebihan gizi juga meningkat.

Menurut laporan dari Global Nutrition Report (2014), Indonesia masuk kedalam 17 negara yang memiliki 3 permasalahan gizi sekaligus, yaitu stunting (pendek), wasting (kurus), dan juga overweight (obesitas). Berdasarkan data riset kesehatan dasar (Riskesdas, 2013) disebutkan bahwa jumlah balita yang mengalami gangguan obesitas menurut BB/TB pada anak usia 0-59 bulan sebesar $11,8 \%$ sedangkan berdasarkan data survey pemantauan status gizi (PSG, 2015) disebutkan bahwa jumlah balita yang mengalami gangguan obesitas menurut $\mathrm{BB} / \mathrm{TB}$ usia $0-59$ bulan sebesar $5,3 \%$. Obesitas dapat menjadi awal dari berbagai penyakit. Maka dari itu pemberian gizi yang berlebihan bagi balitapun tidak baik, penerapan gizi seimbanglah yang seharusnya diberikan dan dapat di kontrol oleh para orang tua [1]

Prinsip nilai gizi seimbang adalah dengan membiasakan pola konsumsi beragam secara seimbang sesuai dengan kebutuhan masing-masing anggota keluarga. Kebiasaan pola hidup sehat secara rutin dengan melakukan aktivitas fisik dan memantau berat badan secara teratur. Pola makan pada balita berpengaruh terhadap keadaan gizi. Gizi yang optimal sangat penting untuk pertumbuhan normal serta perkembangan fisik dan kecerdasan pada anak. Dengan gizi yang baik tubuh tidak mudah terkena serangan penyakit, dan infeksi serta terlindung dari penyakit kronis [2] 
Kekurangan gizi merupakan salah satu masalah yang dialami balita di Indonesia. Peran Puskesmas dan Posyandu sangat diperlukan untuk mengurangi jumlah gizi buruk pada balita. Penting sekali memberi balita asupan gizi seimbang pada tahap yang benar, agar bayi tumbuh sehat dan terbiasa dengan pola hidup sehat di masa yang akan datang. Makanan yang bergizi tidak selalu harus mahal. Peran orang tua dalam memilih jenis makanan yang bisa mencukup nilai gizi balitanya sangatlah penting. Pengelompokannilai gizi pada balita dengan menggunakan metode k-Means ke dalam 5 cluster yaitu gizi buruk, gizi kurang, gizi baik, gizi lebih, obesitas [3].

Status gizi pada balita dapat diketahui berdasarkan indeks Berat Badan menurut umur $(\mathrm{BB} / \mathrm{U})$, Tinggi Badan menurut umur $(\mathrm{TB} / \mathrm{U})$, dan Berat Badan menurut Tinggi Badan (BB/TB) dengan memasukan data nilai dari berat badan, tinggi badan serta jenis kelamin balita. Salah satu cara untuk mengukur tubuh manusia dalam menentukan status gizi anak yaitu antropemetri. Pengukuran antropemetri secara umum berdasarkan Berat Badan menurut umur $(\mathrm{BB} / \mathrm{U})$ dan Tinggi Badan menurut umur $(\mathrm{TB} / \mathrm{U})$. penggunaan antropemetri yang sering digunakan untuk mengukur dari status gizi balita, hal ini disebabkan sederhana dan aman pada tahap pengukuran serta tidak membutuhkan tenaga ahli. Hasil dari antropemetri berupa data yang akurat serta mampu mendeteksi riwayat gizi di masa lampau. Model pengujian dilakukan menggunakan clustering Data mining dengan metode K-Means berdasarkan berat badan dan tinggi badan [4].

Upaya antisipasi bertambahnya kasus gizi buruk pada anak balita, diperlukan peningkatan informasi dan pengetahuan akan pola asuh dan pola makan yang baik dan benar. Pentingnya partisipasi dari orang tua serta petugas Pos Pelayanan Terpadu atau Posyandu untuk memantau nilai gizi balita sangat dibutuhkan.

Pengukuran tinggi badan balita belum banyak dilakukan oleh para orang tua. Walaupun ada, pengukuran belum dilakukan secara standar. Padahal dengan mengontrol secara rutin tinggi badan dan berat badan anak, kita dapat memamtau kondisi gizi anak itu sendir. Jika para orang tua tidak memiliki alat pendukung tersebut, maka para orang tua seharusnya rutin menggunjugi Posyandu yang diadakan setiap bulannya oleh pihak Desa/Kelurahan setempat agar kondisi nilai gizi anak bias tetap terpantau.

Posyandu itu sendiri adalah kegiatan dasar yang diselenggarakan dari, oleh dan untuk masyarakat yang dibantu oleh petugas kesehatan disuatu wilayah Puskesmas. Biasanya secara rutin dalam periode satu bulan sekali Posyandu akan diadakan. Selain memberikan layanan kesehatan ibu dan anak, disini juga balita akan ditimbang berat badan dan diukur secara rutin tinggi badannya agar dapat mengetahui tumbuh kembang sang anak terutama mengenai perkembangan nilai gizinya.

Oleh sebab itu pengolahan data dilakukan pada beberapa Posyandu di Desa Sukamantri yang nantinya data tersebut akan dikelompokan sesuai dengan karakteristik gizi masing- masing anak (analisis hasil pengklasteran) melalui dua parameter yaitu berat badan balita (BB) dan tinggi badan balita (TB). Pengklasteran menggunakan algoritma K-Means merupakan salah satu metode data mining yang cukup populer dalam pengolahan data dan cukup efektif pada saat pengelompokan data dengan ukuran besar dalam kelas-kelas yang memiliki kemiripan.

\section{METODOLOGI PENELITIAN}

Pada penelitian ini dilakukan pada kader Posyandu di Desa Sukamantri Bogor untuk mengetahui tumbuh kembang balita secara periodik. Data yang digunakan adalah data balita dari Posyandu, Kartu Menuju Sehat (KMS), Tinggi Balita (TB) dan Berat Badan (BB) dengan rentan usia balita 0 sampai 36 bulan. Model pengolahan data yang digunakan dalam penelitian ini adalah Data Mining dengan menggunakan metode K-Means. Data balita yang akan dikelompokan berdasarkan data balita Posyandu di Desa Sukamantri Bogor pada tahun 2018. Tools yang digunakan untuk mengolah data menggunakan Microsoft Excel dan Rapid Miner.

\section{A. Data Mining}

Data mining merupakan sebuah cara untuk menemukan pola yang menarik dan pengetahuan dalam jumlah datayang besar. Pada data mining menggunakan teknik matematika, statistik, artificial intelegent serta machine learning untuk mengidentifikasi dan mengekstrasi menjadi informasi atau pengetahuan yang bermanfaat yang diambil dari berbagai database yang besar [5].

\section{B. Clustering}

Cluster merupakan kumpulan objek data yang memiliki kemiripan antara satu dengan yang lain dalam kelompok yang sama dan berbeda objek dengan data kelompok lain. Clustering atau lebih dikenal dengan analisis cluster merupakan proses pengelompokan satu set benda fisik ataupun abstrak ke dalan satu kelas objek yang sama [6]

\section{K-Means Clustering}

K-Means merupakan metode penganalisaan data pada Data Mining dimana proses pemodelan tanpa supervisi dan merupakan salah satu metode yang mengelompokan data secara partisi. Pada metode K-Means data dikelompokan menjadi beberapa kelompok dimana setiap kelompok mempunyai karakteristik yang mirip atau sama dengan lainnya namun dengan kelompok lainnya memiliki karakteristik yang berbeda. Metode ini menimalisasi perbedaan antar data di dalam satu cluster serta memaksimalkan perbedaan dengan cluster yang lain [4].

Metode K-Means memiliki karakteristik sebagai berikut [5]:

1. K-Means merupakan metode pengelompokan yang sederhana dan dapat digunakan dengan mudah. 
2. Pada jenis data set tertentu, K-Means tidak dapat melakukan segmentasi data dengan baik di mana hasil segmentasi tidak dapat menentukan pola kelompok yang mewakili karakteristik bentuk alami data.

3. K-Means bias menalami masalah ketika mengelompokkan data yang mengandung outlier.

Secara umum metode K-Means menggunakan algoritma sebagai berikut [7] :

a. Tentukan $\mathrm{k}$ sebagai jumlah cluster yang di bentuk. Penentuan banyaknya jumlah cluster k dilakukan dengan beberapa faktor seperti pertimbangan teoritis dan konseptual yang diusulkan untuk menentukan berapa banyak cluster.

b. Bangkitkan k Centroid (titik pusat cluster) awal secara random. Untuk menentukan centroid awal dilakukan secara acak dari beberapa objek yang tersedia sebanyak $\mathrm{k}$ cluster, untuk menghitung centroid cluster ke-i berikutnya, menggunakan rumus sebagai berikut:

$$
v=\frac{\sum_{i=1}^{n} x_{i}}{n} \quad ; i=1,2,3, \ldots n
$$

Dimana; v: centroid pada cluster

Xi: objek ke-i

n: banyaknya objek atau jumlah objek yang menjadi anggota cluster

c. Hitung jarak setiap objek ke masing-masing centroid dari masing-masing cluster. Kemudian hitung jarak antara objek dengan centroid, dalam penelitian ini menggunakan Euclidian Distance.

$$
d(x, y)=\|x-y\|=\sqrt{\sum_{i=1}^{n}\left(x_{i}-y_{i}\right)^{2}} \quad ; i=1,2,3, \ldots, n
$$

Dimana; xi : objek x ke-i

$$
\begin{aligned}
& \text { y: daya y ke-i } \\
& \text { n: banyaknya objek }
\end{aligned}
$$

d. Alokasikan masing-masing objek ke dalam centroid yang paling terdekat.

e. Lakukan iterasi, kemudian tentukan posisi centroid baru dengan menggunakan persamaan

f. Ulangi langkah 3 jika posisi centroid baru tidak sama.

Proses penggabungan titik dilakukan dengan membandingkan matriks kumpulan tugas-tugas pada iterasi sebelumnya dengan matrik kumpulan tugas-tugas pada iterasi yang sedang berjalan. Jika hasilnya sama maka algoritma kmeans cluster analysis sudah konvergen, tetapi jika berbeda maka belum konvergen sehingga perlu dilakukan iterasi berikutnya.

\section{Populasi dan Sampel}

Populasi yang digunakan sebagai objek penelitian terdiri dari 118 populasi yang dipilih menggunakan teknik propability samping. Dari jumlah populasi tersebut dihitung menggunakan rumus Slovin sebagai berikut:

$$
n=\frac{N}{1+N e^{2}}
$$

Dimana; n : ukuran sampel

$\mathrm{N}$ : ukuran populasi

e: kelonggaran ketidaktelitian karena kesalahan dimana:

$\mathrm{n}=118 /(1+(118)(0.0025)$

$\mathrm{n}=91.12$ dibulatkan menjadi 91

Berdasarkan rumus tersebut maka besarnya jumlah sampel adalah 91 balita. Berikut ini data Tinggi Badan (BT) dan Berat Badan (BB) pada Posyandu Desa Sukamantri.

TABEL I

DATA TINGGI BADAN DAN BERAT BADAN BALITA

\begin{tabular}{|c|c|c|}
\hline Balita Ke- & Tinggi Badan (TB) & Berat Badan (BB) \\
\hline Balita Ke-1 & 107 & 14 \\
\hline Balita Ke-2 & 79 & 10,5 \\
\hline Balita Ke-3 & 76 & 9,2 \\
\hline Balita Ke-4 & 94 & 13 \\
\hline Balita Ke-5 & 82 & 12 \\
\hline Balita Ke-6 & 80 & 8 \\
\hline Balita Ke-7 & 87 & 11 \\
\hline Balita Ke-8 & 75 & 8 \\
\hline Balita Ke-9 & 70 & 9,8 \\
\hline Balita Ke-10 & 68 & 8,8 \\
\hline Balita Ke-11 & 98 & 13 \\
\hline Balita Ke-12 & 76 & 9,1 \\
\hline Balita Ke-13 & 75 & 8,9 \\
\hline Balita Ke-14 & 74 & 8 \\
\hline Balita Ke-15 & 88 & 11 \\
\hline Balita Ke-16 & 89 & 13 \\
\hline Balita Ke-17 & 87 & 9,8 \\
\hline Balita Ke-18 & 92 & 18 \\
\hline Balita Ke-19 & 87 & 12 \\
\hline Balita Ke-20 & 85 & 9,7 \\
\hline Balita Ke-21 & 75 & 10 \\
\hline Balita Ke-22 & 68 & 7,5 \\
\hline Balita Ke-23 & 75 & 6,5 \\
\hline Balita Ke-24 & 78 & 11,8 \\
\hline Balita Ke-25 & 78 & \\
\hline Balita Ke-26 & 60 & 8,5 \\
\hline Balita Ke-27 & 68 & \\
\hline Balita Ke-28 & 91 & 8,5 \\
\hline & & \\
\hline
\end{tabular}




\begin{tabular}{|c|c|c|}
\hline Balita Ke-29 & 78 & 10,5 \\
\hline Balita Ke-30 & 85 & 10,7 \\
\hline Balita Ke-31 & 76 & 8 \\
\hline Balita Ke-32 & 63 & 7,1 \\
\hline Balita Ke-33 & 71 & 8 \\
\hline Balita Ke-34 & 79 & 10,2 \\
\hline Balita Ke-35 & 71 & 8,1 \\
\hline Balita Ke-36 & 81 & 8 \\
\hline Balita Ke-37 & 78 & 9,5 \\
\hline Balita Ke-38 & 74 & 10,5 \\
\hline Balita Ke-39 & 65 & 9 \\
\hline Balita Ke-40 & 74 & 8,4 \\
\hline Balita Ke-41 & 86 & 11 \\
\hline Balita Ke-42 & 92 & 14 \\
\hline Balita Ke-43 & 84 & 12 \\
\hline Balita Ke-44 & 87 & 12,6 \\
\hline Balita Ke-45 & 88 & 9,2 \\
\hline Balita Ke-46 & 72 & 9 \\
\hline Balita Ke-47 & 80 & 10,2 \\
\hline Balita Ke-48 & 64 & 8,3 \\
\hline Balita Ke-49 & 73 & 8 \\
\hline Balita Ke-50 & 72 & 8 \\
\hline Balita Ke-51 & 80 & 12,1 \\
\hline Balita Ke-52 & 85 & 10,2 \\
\hline Balita Ke-53 & 65 & 7,5 \\
\hline Balita Ke-54 & 79 & 9,6 \\
\hline Balita Ke-55 & 76 & 7,7 \\
\hline Balita Ke-56 & 84 & 9,8 \\
\hline Balita Ke-57 & 99 & 15 \\
\hline Balita Ke-58 & 88 & 20,2 \\
\hline Balita Ke-59 & 86 & 11,7 \\
\hline Balita Ke-60 & 80 & 10 \\
\hline Balita Ke-61 & 77 & 8,7 \\
\hline Balita Ke-62 & 68 & 8 \\
\hline Balita Ke-63 & 75 & 8 \\
\hline Balita Ke-64 & 77 & 10,5 \\
\hline Balita Ke-65 & 92 & 14 \\
\hline Balita Ke-66 & 69 & 7,3 \\
\hline Balita Ke-67 & 69 & 8,2 \\
\hline Balita Ke-68 & 61 & 9 \\
\hline Balita Ke-69 & 70 & 7,5 \\
\hline Balita Ke-70 & 64 & 7,4 \\
\hline Balita Ke-71 & 66 & 7,4 \\
\hline Balita Ke-72 & 63 & 9,9 \\
\hline Balita Ke-73 & 62 & 8,1 \\
\hline Balita Ke-74 & 77 & 10 \\
\hline
\end{tabular}

\begin{tabular}{|c|c|c|} 
Balita Ke-75 & 83 & 11 \\
\hline Balita Ke-76 & 80 & 9,9 \\
\hline Balita Ke-77 & 82 & 9 \\
\hline Balita Ke-78 & 82 & 16 \\
\hline Balita Ke-79 & 87 & 13 \\
\hline Balita Ke-80 & 76 & 8,7 \\
\hline Balita Ke-81 & 66 & 8,5 \\
\hline Balita Ke-82 & 78 & 9 \\
\hline Balita Ke-83 & 82 & 10,2 \\
\hline Balita Ke-84 & 69 & 8,5 \\
\hline Balita Ke-85 & 63 & 9 \\
\hline Balita Ke-86 & 86 & 11,7 \\
\hline Balita Ke-87 & 61 & 13 \\
\hline Balita Ke-88 & 84 & 13 \\
\hline Balita Ke-89 & 92 & 17 \\
\hline Balita Ke-90 & 70 & 6 \\
\hline Balita Ke-91 & 70 & 9 \\
\hline
\end{tabular}

\section{HASIL DAN PEMBAHASAN}

Tujuan dari penelitian ini adalah untuk melakukan klasterisasi nilai gizi balita pada Desa Sukamantri Bogor menggunakan metode K-Means.

\section{A. Perhitungan Normalisasi}

Data balita yang ada pada tabel 1 tidak dapat langsung diolah dikarenakan adanya perbedaan besaran angka yang cukup jauh antara variabel tinggi badan dan berat badan. Solusi yang digunakan untuk memperkecil besaran angka adalah dengan melakukan normalisasi pada variabel tinggi badan dan berat badan dengan menggunakan rumus:

\section{Nilai Normalisasi $=\frac{(\text { Nilai Awal }- \text { Nilai Minimum })}{(\text { Nilai Maksimal }- \text { Nilai Minimum })}$}

Berdasarkan nilai variabel tinggi badan dan berat badan akan dilakukan proses normalisasi ke dalam rentang 0 sampai 1. Proses normalisasi dibutuhkan sebelum perhitungan nilai centroid pada K-Means. Hasil perhitungan nilai normalisasi berdasarkan tabel I sebagai berikut:

TABEL II

NILAI NORMALISASI TINGGI BADAN DAN BERAT BADAN BALITA

\begin{tabular}{|l|c|c|}
\hline \multicolumn{1}{|c|}{ Balita ke- } & Tinggi Badan(TB) & Berat Badan(BB) \\
\hline Balita Ke-1 & 0.681 & 0.563 \\
\hline Balita Ke-2 & 0.468 & 0.317 \\
\hline Balita Ke-3 & 0.340 & 0.225 \\
\hline
\end{tabular}




\begin{tabular}{|c|c|c|}
\hline Balita Ke-4 & 0.574 & 0.493 \\
\hline Balita Ke-5 & 0.553 & 0.423 \\
\hline Balita Ke-6 & 0.128 & 0.141 \\
\hline Balita Ke-7 & 0.511 & 0.352 \\
\hline Balita Ke-8 & 0.139 & 0.141 \\
\hline Balita Ke-9 & 0.383 & 0.268 \\
\hline Balita Ke-10 & 0.298 & 0.197 \\
\hline Balita Ke-11 & 0.596 & 0.493 \\
\hline Balita Ke-12 & 0.340 & 0.220 \\
\hline Balita Ke-13 & 0.319 & 0.204 \\
\hline Balita Ke-14 & 0.170 & 0.141 \\
\hline Balita Ke-15 & 0.511 & 0.352 \\
\hline Balita Ke-16 & 0.596 & 0.493 \\
\hline Balita Ke-17 & 0.383 & 0.268 \\
\hline Balita Ke-18 & 0.830 & 0.845 \\
\hline Balita Ke-19 & 0.574 & 0.423 \\
\hline Balita Ke-20 & 0.383 & 0.261 \\
\hline Balita Ke-21 & 0.426 & 0.282 \\
\hline Balita Ke-22 & 0.064 & 0.106 \\
\hline Balita Ke-23 & 0.362 & 0.246 \\
\hline Balita Ke-24 & 0.170 & 0.141 \\
\hline Balita Ke-25 & 0.362 & 0.246 \\
\hline Balita Ke-26 & 0.085 & 0.106 \\
\hline Balita Ke-27 & 0.021 & 0.028 \\
\hline Balita Ke-28 & 0.553 & 0.408 \\
\hline Balita Ke-29 & 0.468 & 0.317 \\
\hline Balita Ke-30 & 0.511 & 0.331 \\
\hline Balita Ke-31 & 0.170 & 0.141 \\
\hline Balita Ke-32 & 0.021 & 0.077 \\
\hline Balita Ke-33 & 0.170 & 0.141 \\
\hline Balita Ke-34 & 0.426 & 0.296 \\
\hline Balita Ke-35 & 0.213 & 0.148 \\
\hline Balita Ke-36 & 0.191 & 0.141 \\
\hline Balita Ke-37 & 0.383 & 0.246 \\
\hline Balita Ke-38 & 0.468 & 0.317 \\
\hline Balita Ke-39 & 0.319 & 0.211 \\
\hline Balita Ke-40 & 0.255 & 0.169 \\
\hline Balita Ke-41 & 0.532 & 0.352 \\
\hline
\end{tabular}

\begin{tabular}{|c|c|c|}
\hline Balita Ke-42 & 0.681 & 0.552 \\
\hline Balita Ke-43 & 0.574 & 0.423 \\
\hline Balita Ke-44 & 0.574 & 0.465 \\
\hline Balita Ke-45 & 0.361 & 0.225 \\
\hline Balita Ke-46 & 0.319 & 0.211 \\
\hline Balita Ke-47 & 0.426 & 0.296 \\
\hline Balita Ke-48 & 0.234 & 0.162 \\
\hline Balita Ke-49 & 0.191 & 0.141 \\
\hline Balita Ke-50 & 0.191 & 0.141 \\
\hline Balita Ke-51 & 0.574 & 0.430 \\
\hline Balita Ke-52 & 0.447 & 0.296 \\
\hline Balita Ke-53 & 0.085 & 0.106 \\
\hline Balita Ke-54 & 0.383 & 0.254 \\
\hline Balita Ke-55 & 0.106 & 0.120 \\
\hline Balita Ke-56 & 0.404 & 0.268 \\
\hline Balita Ke-57 & 0.681 & 0.634 \\
\hline Balita Ke-58 & 1.000 & 1.000 \\
\hline Balita Ke-59 & 0.532 & 0.401 \\
\hline Balita Ke-60 & 0.426 & 0.282 \\
\hline Balita Ke-61 & 0.298 & 0.190 \\
\hline Balita Ke-62 & 0.213 & 0.141 \\
\hline Balita Ke-63 & 0.213 & 0.141 \\
\hline Balita Ke-64 & 0.489 & 0.317 \\
\hline Balita Ke-65 & 0.681 & 0.563 \\
\hline Balita Ke-66 & 0.043 & 0.092 \\
\hline Balita Ke-67 & 0.234 & 0.159 \\
\hline Balita Ke-68 & 0.319 & 0.211 \\
\hline Balita Ke-69 & 0.106 & 0.106 \\
\hline Balita Ke-70 & 0.064 & 0.099 \\
\hline Balita Ke-71 & 0.064 & 0.099 \\
\hline Balita Ke-72 & 0.404 & 0.275 \\
\hline Balita Ke-73 & 0.213 & 0.148 \\
\hline Balita Ke-74 & 0.426 & 0.282 \\
\hline Balita Ke-75 & 0.544 & 0.373 \\
\hline Balita Ke-76 & 0.404 & 0.275 \\
\hline Balita Ke-77 & 0.319 & 0.211 \\
\hline Balita Ke-78 & 0.787 & 0.704 \\
\hline Balita Ke-79 & 0.596 & 0.493 \\
\hline
\end{tabular}




\begin{tabular}{|l|l|l|} 
Balita Ke-80 & 0.298 & 0.190 \\
\hline Balita Ke-81 & 0.255 & 0.176 \\
\hline Balita Ke-82 & 0.340 & 0.211 \\
\hline Balita Ke-83 & 0.468 & 0.296 \\
\hline Balita Ke-84 & 0.277 & 0.176 \\
\hline Balita Ke-85 & 0.340 & 0.211 \\
\hline Balita Ke-86 & 0.553 & 0.401 \\
\hline Balita Ke-87 & 0.606 & 0.493 \\
\hline Balita Ke-88 & 0.660 & 0.493 \\
\hline Balita Ke-89 & 0.809 & 0.775 \\
\hline Balita Ke-90 & 0.000 & 0.00 \\
\hline Balita Ke-91 & 0.340 & 0.211 \\
\hline
\end{tabular}

memiliki jarak 0.725. Pada cluster 3 memiliki jarak 0.476 . Dan pada cluster 5 memiliki jarak 0.213. Dari ke-5 cluster tersebut, data balita ke-1 memiliki jarak terpendek dengan cluster 4. Oleh karena itu data balita ke-1 masuk ke dalam cluster 4. Langkah yang sama diterapkan di ke-50 data untuk melakukan pengelompokan di iterasi 1 .

TABEL IIIV

PENDEKATAN CLUSTER DENGAN JARAK TERDEKAT

\begin{tabular}{|l|l|l|l|l|l|}
\hline Balita Ke- & $\begin{array}{l}\text { Jarak } \\
\text { C0 }\end{array}$ & $\begin{array}{l}\text { Jarak } \\
\text { C1 }\end{array}$ & $\begin{array}{l}\text { Jarak } \\
\text { C2 }\end{array}$ & $\begin{array}{l}\text { Jarak } \\
\text { C3 }\end{array}$ & $\begin{array}{l}\text { Jarak } \\
\text { C4 }\end{array}$ \\
\hline Balita Ke-1 & & & & & $*$ \\
\hline Balita Ke-2 & & & $*$ & & \\
\hline Balita Ke-3 & & & $*$ & & \\
\hline Balita Ke-4 & & & & & $*$ \\
\hline Balita Ke-5 & & $*$ & & & \\
\hline Balita Ke-6 & & & $*$ & & \\
\hline Balita Ke-7 & & $*$ & & & \\
\hline Balita Ke-8 & & & $*$ & & \\
\hline Balita Ke-9 & $*$ & & & & \\
\hline Balita Ke-10 & $*$ & & & & \\
\hline Balita Ke-11 & & & & & $*$ \\
\hline Balita Ke-12 & & & $*$ & & \\
\hline Balita Ke-13 & & & $*$ & & \\
\hline Balita Ke-14 & & & $*$ & & \\
\hline Balita Ke-15 & & $*$ & & & \\
\hline Balita Ke-16 & & $*$ & & & \\
\hline Balita Ke-17 & & $*$ & & & \\
\hline Balita Ke-18 & & & & $*$ & \\
\hline Balita Ke-19 & & $*$ & & & \\
\hline Balita Ke-20 & & $*$ & & & \\
\hline Balita Ke-21 & & & $*$ & & \\
\hline Balita Ke-22 & $*$ & & & & \\
\hline Balita Ke-23 & & & $*$ & & \\
\hline Balita Ke-24 & & & $*$ & & \\
\hline Balita Ke-25 & & & $*$ & & \\
\hline Balita Ke-26 & $*$ & & & & \\
\hline Balita Ke-27 & $*$ & & & & \\
\hline Balita Ke-28 & & $*$ & & & \\
\hline Balita Ke-29 & & & $*$ & & \\
\hline
\end{tabular}

\section{B. Nilai Initial Cluster Center}

Setelah data tinggi badan berat badan dilakukan normalisasi seperti pada tabel II, langkah selanjutnya adalah menentukan jumlah kelompok atau cluster. Ke-91 data balita yang ada di tabel sebelumnya akan dikelompokkan ke dalam 5 cluster yaitu : Obesitas, Gizi Lebih, Gizi baik, Gizi kurang, Gizi Buruk. Setelah jumlah cluster ditentukan, langkah selanjutnya adalah melakukan menentukan nilai initial cluster centre untuk masing-masing cluster pada setiap variabelnya.

Untuk menentukan centroid awal (initial centroid) banyak metode yang dapat digunakan. Dalam penelitian ini metode yang digunakan untuk pengambilan data dari data sumber, secara acak. Berikut penetapan nilai Initial Cluster Center awal yang telah di pilih secara random:

TABEL IIII

Nilai INITIAL Cluster Center

\begin{tabular}{|c|l|c|c|}
\hline Cluster & Status Gizi & TB $(\mathbf{c m})$ & BB $(\mathbf{K g})$ \\
\hline 0 & Obesitas & 0.139 & 0.159 \\
\hline 1 & Gizi Lebih & 0.544 & 0.373 \\
\hline 2 & Gizi Baik & 0.361 & 0.220 \\
\hline 3 & Gizi Kurang & 0.606 & 0.831 \\
\hline 4 & Gizi Buruk & 0.787 & 0.552 \\
\hline
\end{tabular}

\section{Pengelompokan Data Cluster}

Setelah masing-masing data dihitung jaraknya untuk tiap cluster, langkah selanjutnya adalah mengelompokkan data sesuai clusternya. Kelompok cluster suatu data diambil dari jarak terpendek data tersebut terhadap suatu cluster. Misalkan untuk data Balita ke-1 memiliki jarak 0.9452 terhadap cluster 0 . Pada cluster 1 memiliki jarak 0.494. Pada cluster 2 


\begin{tabular}{|c|c|c|c|c|c|}
\hline Balita Ke-31 & & & $*$ & & \\
\hline Balita Ke-32 & $*$ & & & & \\
\hline Balita Ke-33 & $*$ & & & & \\
\hline Balita Ke-34 & & & $*$ & & \\
\hline Balita Ke-35 & $*$ & & & & \\
\hline Balita Ke-36 & & & $*$ & & \\
\hline Balita Ke-37 & & & $*$ & & \\
\hline Balita Ke-38 & & & $*$ & & \\
\hline Balita Ke-39 & $*$ & & & & \\
\hline Balita Ke-40 & & & $*$ & & \\
\hline Balita Ke-41 & & $*$ & & & \\
\hline Balita Ke-42 & & & & & $*$ \\
\hline Balita Ke-43 & & $*$ & & & \\
\hline Balita Ke-44 & & $*$ & & & \\
\hline Balita Ke-45 & & $*$ & & & \\
\hline Balita Ke-46 & & & $*$ & & \\
\hline Balita Ke-47 & & & $*$ & & \\
\hline Balita Ke-48 & $*$ & & & & \\
\hline Balita Ke-49 & & & $*$ & & \\
\hline Balita Ke-50 & $*$ & & & & \\
\hline Balita Ke-51 & & $*$ & & & \\
\hline Balita Ke-52 & & $*$ & & & \\
\hline Balita Ke-53 & $*$ & & & & \\
\hline Balita Ke-54 & & & $*$ & & \\
\hline Balita Ke-55 & & & $*$ & & \\
\hline Balita Ke-56 & & $*$ & & & \\
\hline Balita Ke-57 & & & & & $*$ \\
\hline Balita Ke-58 & & & & $*$ & \\
\hline Balita Ke-59 & & $*$ & & & \\
\hline Balita Ke-60 & & & $*$ & & \\
\hline Balita Ke-61 & & & $*$ & & \\
\hline Balita Ke-62 & $*$ & & & & \\
\hline Balita Ke-63 & & $*$ & & & \\
\hline Balita Ke-64 & & $*$ & & & \\
\hline Balita Ke-65 & & & & & * \\
\hline Balita Ke-66 & $*$ & & & & \\
\hline Balita Ke-67 & $*$ & & & & \\
\hline Balita Ke-68 & $*$ & & & & \\
\hline
\end{tabular}

\begin{tabular}{|l|l|l|l|l|l|}
\hline Balita Ke-69 & $*$ & & & & \\
\hline Balita Ke-70 & $*$ & & & & \\
\hline Balita Ke-71 & $*$ & & & & \\
\hline Balita Ke-72 & $*$ & & & & \\
\hline Balita Ke-73 & $*$ & & & & \\
\hline Balita Ke-74 & & & $*$ & & \\
\hline Balita Ke-75 & & $*$ & & & \\
\hline Balita Ke-76 & & & $*$ & & \\
\hline Balita Ke-77 & & & $*$ & & \\
\hline Balita Ke-78 & & & & $*$ & \\
\hline Balita Ke-79 & & $*$ & & & \\
\hline Balita Ke-80 & & & $*$ & & \\
\hline Balita Ke-81 & $*$ & & & & \\
\hline Balita Ke-82 & & & $*$ & & \\
\hline Balita Ke-83 & & $*$ & & & \\
\hline Balita Ke-84 & $*$ & & & & \\
\hline Balita Ke-85 & $*$ & & & & \\
\hline Balita Ke-86 & & $*$ & & & \\
\hline Balita Ke-87 & $*$ & & & & \\
\hline Balita Ke-88 & & $*$ & & & \\
\hline Balita Ke-89 & & & & $*$ & \\
\hline Balita Ke-90 & $*$ & & & & \\
\hline Balita Ke-91 & $*$ & & & & \\
\hline
\end{tabular}

\section{Penentuan Nilai Centroid Baru}

Setelah pengelompokan selesai, maka selanjutnya adalah menghitung nilai centroid baru dengan cara menghitung berdasarkan pengelompokan tabel.

Berikut ini hasil pengelompokan dari 91 data balita dan jaraknya:

TABEL IVV

NILAI CENTROID BARU

\begin{tabular}{|c|c|c|c|c|c|}
\cline { 2 - 6 } \multicolumn{1}{c|}{} & \multicolumn{5}{c|}{ Nilai Centroid Baru } \\
\cline { 2 - 6 } & C0 & C1 & C2 & C3 & C4 \\
\hline $\begin{array}{c}\text { Tinggi } \\
\text { Badan }\end{array}$ & 0.139 & 0.544 & 0.361 & 0.606 & 0.787 \\
\hline $\begin{array}{c}\text { Berat } \\
\text { Badan }\end{array}$ & 0.159 & 0.373 & 0.220 & 0.831 & 0.552 \\
\hline
\end{tabular}


Setelah nilai centroid baru dihitung, langkah selanjutnya adalah dibandingkan dengan nilai centroid sebelumnya (pada iterasi ini dibandingkan dengan nilai Initial Cluster Centre). Jika nilainya sama maka proses iterasi dihentikan. Namun jika nilainya tidak sama, maka proses pengelompokan data diulangi kembali.

Berikut ini hasil pengolahan data nilai gizi balita menggunakan rapid miner, terlihat pada gambar 1 :

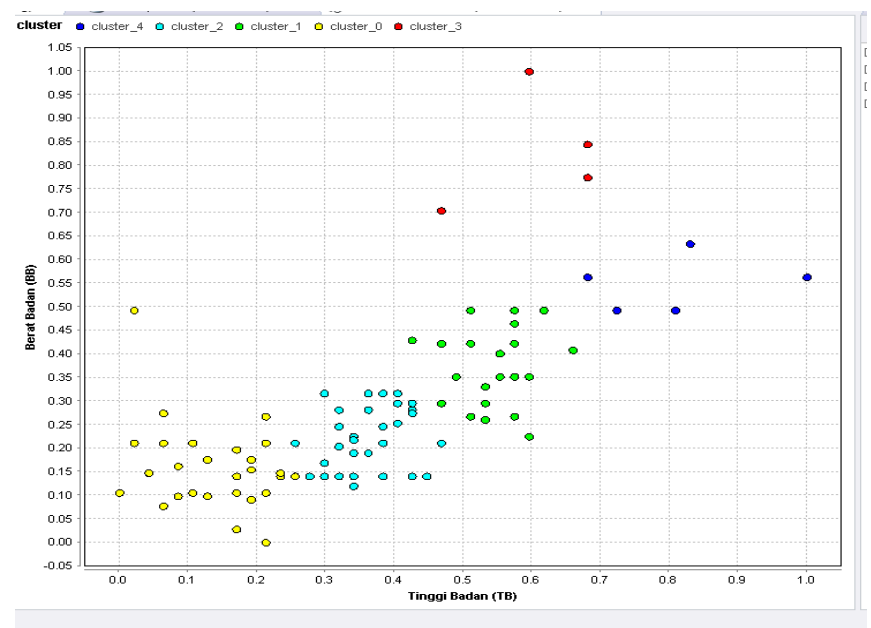

Gambar. 1 Hasil chart clustering

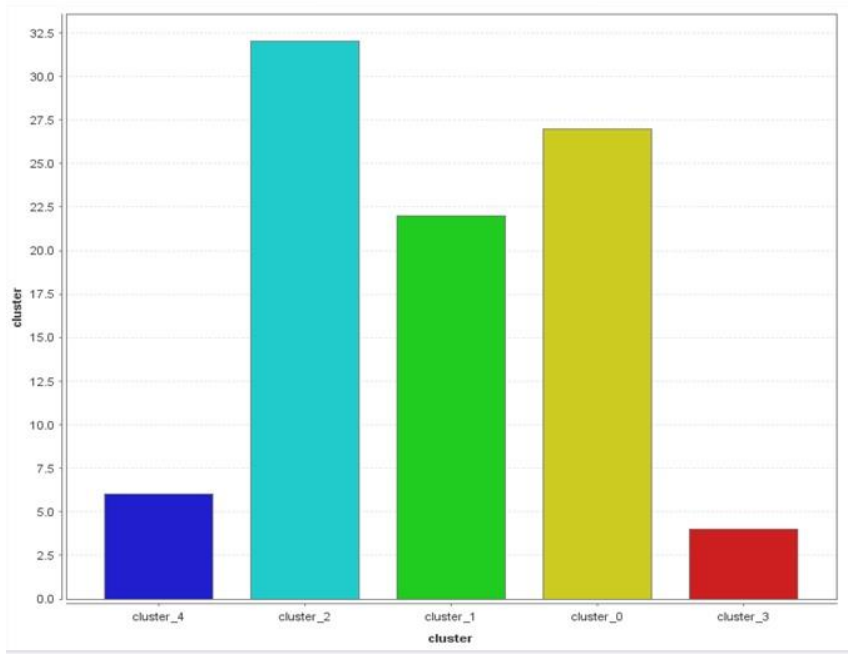

Gambar. 2 Hasil grafik pengelompokan nilai gizi

Pada gambar 2 didapat hasil pengelompokan nilai gizi balita menggunakan K-Means. Berdasarkan hasil klasterisasi berdasarkan nilai gizi pada Desa Sukamantri Bogor didapatkan 5 cluster pengelompokan dimana terdapat $30 \%$ balita obesitas, $24 \%$ balita gizi lebih, $35 \%$ gizi baik, $4 \%$ gizi kurang dan $7 \%$ gizi buruk.

\section{KESIMPULAN}

Berdasarkan hasil penelitian ini bahwa nilai gizi balita Desa Sukamantri Bogor dapat diklasterisasikan dengan menggunakan algoritma K-Means melalui dua parameter Berat Badan Balita (BB) dan Tinggi Badan Balita (TB) dimana dibagi menjadi 5 cluster yaitu obesitas, gizi lebih, gizi baik, gizi kurang dan gizi buruk guna membantu kinerja para kader Posyandu dan Orang Tua balita dalam penanganan dini kondisi nilai gizi balita.

Dari hasil tersebut diketahui masih terdapat $30 \%$ balita obesitas serta $11 \%$ balita kekurangan gizi sehingga perlu adanya pendampingan dari Posyandu serta puskesmas terkait kepada orang tua balita sehingga jumlah balita yang kekurangan gizi dapat menurun di tahun berikutnya.

\section{REFERENSI}

[1] Kementerian Kesehatan Republik Indonesia, Hasil Pemantauan Status Gizi ( Psg ) Tahun 2017. Jakarta, 2018.

[2] Kementerian Kesehatan Republik Indonesia, Pedoman Gizi Seimbang. Jakarta, 2014.

[3] W. M. pradnya Dhuhita, "Clustering Menggunakan Metode K-Means untuk Menentukan Status Gizi Balita," J. Inform., vol. 15, no. 2, pp. 160--174, 2015.

[4] P. Sari, B. Pramono, and L. ode H. S. Sagala, "Improve K-Means Terhadap Status Nilai Gizi Pada Balita," semanTIK, vol. 3, no. 1, pp. 143-148, 2017.

[5] E. Prasetyo, Data Mining Konsep dan Aplikasi Menggunakan Matlab. Yogyakarta: Penerbit Andi Yogyakarta, 2012.

[6] J. Han and Kamber, Data Mining Concept and Techniques. India: New Age International Limited, 2006.

[7] Ediyanto, M. N. Mara, and N. Satyahadewi, "Pengklasifikasian Karakteristik Dengan Metod KMeans Cluster Analysis," Bul. Ilm., vol. 2, no. 2, pp. 133-136, 2013. 